\title{
FUNGSI BUAH DAN DAUN TANAMAN DALAM BUDAYA BALI SEBUAH KAJIAN TERHADAP TANAMAN UPACARA
}

\author{
I Nyoman Adiputra \\ Pusat Kajian Ergonomi, Universitas Udayana. \\ E-mail:nadip2003@yahoo.com.
}

\begin{abstract}
Abstrak
Tanaman dalam budaya Bali punya beberapa dimensi, seperti tanaman obat, tanaman upacara, tanaman komoditas, tanaman hias, dan tanaman magis. Sedemikian pentingnya nilai tanaman dalam masyarakat Bali sehingga sampai ada hari untuk tanam-tanaman yang disebut sebagai tumpek $u d u h$, hari persembahan kepada dewa tanaman. Dalam tulisan ini dipaparkan fungsi daun dan buah tanaman sebagai sarana suatu upacara keagamaan. Kajian difokuskan kepada penggunaan buah sebagai phala gantung berupa buah-buahan yang tergantung pada batangnya seperti nangka, manggis, duku, mangga, pakel, wani, jeruk bali, sumaga, sabo, buah naga dan lainnya, atau umbi tanaman sebagai phala bungkah, seperti umbi keladi, umbi ketela rambat, umbi sabrang, umbi bangkuang, segala jenis ubi, umbi kacang tanah; sebagai bentuk persembahan buah/umbi tanaman dalam bentukan sesajen yang dipersembahkan kepada Ida Sanghyang Widi Wasa. Sedangkan daun diwujudkan dalam susunan sesajen catur, panca-, sapta-dala, yang dalam upakara disebut sebagai pancaatau sapta-laywan. Sapta laywan terdiri dari daun pelasa, ancak, sokasti, beringin, nagasari, cemara, dan bunga pinang muda ( belangsah) di bagian paling dalam dalam keadaan tergulung. Hal itu untuk membuat banten catur. Sedangkan untuk tetukon dalam pitra yadnya, atau pesaji untuk dewa yadnya diperlukan catur pala (buah manas, manggis, cereme, duku/ pisang, pangi) atau catur dala (don: buah, manggis, duren, busung). Penyusunan bentuk sesajen tersebut semata-mata didasarkan atas warna buah atau daun. Orientasinya bersumber kepada tatwa pangider-ideran (arah mata angin). Air kelapa muda diperlukan dalam proses pembersihan (panglukatan), seperti nyuh bulan (di timur), nyuh rangda (tenggara), nyuh udang (selatan), nyuh surya (barat daya), nyuh gading (barat), nyuh be julit (barat laut), nyuh mulung (utara), nyuh bojog (timur laut), nyuh sudamala (tengah-tengah). Tujuannya adalah wujud persembahan manusia dengan memanfaatkan bahan alam, demi tercapainya kelestarian (pariwerta) dan keseimbangan/keserasian alam semesta (somya), yang digerakkan oleh manusia.
\end{abstract}

Kata kunci: daun, buah, budaya Bali, phala gantung, phala bungkah, asta dala

\section{THE FUNCTIONS OF FRUITSAND LEAVES IN BALINESE CULTURE. An Analysis on Ceremonial Plants.}

\begin{abstract}
According to the Balinese culture, there are some classifications of plants, such as: medicinal plants, ceremonial plants, commodity plants, horticulture, and magical plants. Due to it' very importance value, culturally, there is a special day for the existing plants, called
\end{abstract}


tumpek uduh, where a special offering is intended to the god of plantation. In this article is drawn function of leaves and fruits as a material for offering. Analysis is focused on the use of fruits as pala gantung, pala bungkah or tuber for the offerings to the god. The leaves are used for religious ceremony in term of panca dhala or asta dala. In composing the offerings, there is a guidance derived from tatwa pangider-ideran (point of compass). The used of leaves and fruits, is based on the color of leaves and fruits. The goals are for preserving/ conserving and peace-full fitting of nature. The liquid of young coconut fruits are used for the process of purifications materials, places, and the symbols of religious matters. Starting from east direction: nyuh bulan, east-south: nyuh rangda, south direction: nyuh udang, south west: nyuh surya, west direction: nyuh kuning, west-north: nyuh be julit, north direction: nyuh mulung, and the middle: nyuh sudamala. That is the respective-, dedicative offerings from human being to the nature by making use of materials for the feacefull, safety, and sustainability of the nature itself.

Key words: leaf, fruit, phala gantung, phala bungkah, panca dhala.

\section{Pendahuluan}

Budaya Bali, salah satu budaya Indonesia yang berlandaskan agama Hindu. Kebudayaan Bali telah menjadi pegangan hidup orang Bali dari generasi ke generasi. Pengobatan tradisional Bali adalah salah satunya. Di samping itu termasuk dalam pelaksanaan acara adat dan agama tata caranya harus sesuai dengan pedoman atau tuntunan yang telah diwariskan leluhur (Nala \&Wiratmadja, 1985). Dalam hal itu orang Bali sangat ketat memegang aturan atau norma pelaksanaan acara adat dan agama. Dalam bidang pengobatan tradisional Bali, banyak diperlukan tanaman obat, produk hewan atau bahan alam lainnya seperti logam berat, sebagai bahan obat alami (Adiputra, 2017).

Tanaman obat informasinya bersumber dari lontar, seperti Usada Taru Premana, Usada Parik Kayu, dan Usada Sundari Siksa (Adiputra, 2017). Indonesia sebagai salah satu negara tropis, banyak mempunyai tanaman tropis, yang dapat dimanfaatkan sebagai tanaman obat (Adiputra, 2004). Melihat kenyataan bahwa tanaman obat banyak tumbuh, dan generasi muda Bali tidak tertarik kepada pengobatan tradisional (Adiputra, 2017), akhirnya akan berujung kepada semakin punahnya tanaman obat tropis tersebut. Suara seperti itu banyak disampaikan oleh peneliti asing yang datang berkunjung ke Bali.

Penelitian ilmiah dalam tanaman obat di Bali, telah banyak dilakukan; sehingga dapat disimpulkan bahwa tanaman obat Bali banyak dimanfaatkan sebagai tanaman hias yang ditanam di sekeliling rumah (Adiputra,2005) atau di sekeliling kantor pemerintah (Adiputra, 2006.c) atau bahkan di sekitar hotel berbintang (Adiputra, 2005.a), malahan juga di median jalan (Adiputra, 2005.b). Di samping itu salah satu sisi tanaman obat Bali juga sebagai tanaman upacara, yang digunakan dalam upacara adat dan agama (Tim Peneliti UNUD, 2002; LPMUNUD, 2004). Dengan berbagai dimensi tanaman obat seperti itu, maka tertutuplah kemungkinan punahnya tanaman obat dari muka bumi ini. Sebagai pengamannya, tanaman obat banyak dimanfaatkan sebagai tanaman hias, di samping juga sebagai tanaman komoditas yang bernilai ekonomis. Sisi lainnya tanaman obat juga sebagai tanaman magis (Adiputra, 2005.c; 2008; 2011). Dalam tulisan ini dilaporkan fungsi dari buah dan daun tanaman dalam konteks budaya Bali. Hal itu disebabkan karena daun tanaman dan buahbuahan dipakai sebagai upakara dalam berbagai yadnya, dalami upacara adat dan agama di Bali.

\section{Materi dan Metode}

Materi. Tahap I dilakukan penelitian pustaka mencari petunjuk dalam hubungan tanaman yang dipergunakan dalam yadnya. Setelah itu dilakukan uji lapangan dipertanyakan kembali kepada tokoh di bidangnya, mengkonfirmasikan apakah memang seperti itu, atau masih eksis sampai sekarang. Dalam penelitian ini informasi diperoleh dari studi pustaka berupa lontar (pelutuk bebantenan, buku-buku agama Hindu serta informasi oral dari tokoh sebagai orang ahli di bidang agama Hindu, termasuk ahli dalam upacara agama Hindu. Mengenai nama tanaman diperoleh dari sumber informasi (Suryowinoto, 2001; 2004; Tim Peneliti Unud, 2002; LPM UNUD, 2004). Demikian nama tanaman lokal 
diperoleh, langsung dicari nama Indonesia dan nama ilmiahnya.

\section{Hasil dan Pembahasan}

Hasil-hasil. Dalam penelaahan pustaka diperoleh istilah sebagai berikut: panca phala (yang berarti 5 jenis buah), panca dhala (5 jenis daun), dan bija ratus. Hasil studi tersebutlah yang dikonfirmasikan di lapangan, mengenai eksistensi dan makna, realisasinya dalam pelaksanaan yadnya di masyarakat.

a. Panca Phala. Mengenai panca phala di sini diartikan 5 jenis buah-buahan, yang disesuaikan dengan lima arah mata angin, yaitu timur, barat, utara, selatan dan tengah. Arah tersebut dinyatakan dalam warna sesuai dengan pangider-ideran (Lontar Dasaksara, tt). Warna itulah yang dipakai untuk memilih 5 jenis buah-buahan tersebut.

a.1) Buah cereme (Cicca disticha L.) (Suryowinoto, 2001; 2004; Tim Peneliti Unud, 2002; LPM UNUD, 2004) untuk lokasi di timur. Hal itu dilakukan atas warna buah cereme adalah putih (petak) simbul Dewa Iswara. Kalau buah cereme tidak diperoleh, boleh dipakai buah tingkih atau kemiri (Aleurites moluccana Willd). Daging buah tingkih juga putih warnanya.

a.2) Arah Barat disimbulkan warna kuning untuk Dewa Maha Dewa. Buah yang dipakai untuk itu adalah pisang (Musa paradisiacal L.) (Suryowinoto, 2001; 2004; Tim Peneliti Unud, 2002; LPM UNUD, 2004), karena semua warna pisang yang ranum dagingnya berwana kuning termasuk warna kulitnya. Kalau pisang terkendala, dapat dipakai buah ceroring (duku= ceroring; Lansium domesticum Corr.) (Suryowinoto, 2001; 2004; Tim Peneliti Unud, 2002; LPM UNUD, 2004), karena warna kulit buah yang matang kuning.

a.3) Utara simbul warna hitam untuk Dewa Wisnu dipakai warna gelap seperti hijau atau ungu tua. Buah yang dipakai adalah pangi (Pangium edule Reinw.) (Suryowinoto, 2001; 2004; Tim Peneliti Unud, 2002; LPM UNUD, 2004), karena warna daging buah matangnya hitam. Daging yang warna hitam tersebut ternyata bisa dijadikan makanan dicampur dengan rajangan bawang dan cabai, sehingga disebut sambel pangi. Kalau pangi terkendala, bisa juga dipakai buah poh (Sterculia foetida L.) (Suryowinoto, 2001; 2004; Tim Peneliti Unud, 2002; LPM UNUD, 2004). Mengapa? Karena warna biji poh hitam.

a.4) Untuk arah selatan warna merah simbul Dewa Brahma. Buah yang dipakai adalah buah pinang (Areca catechu L.) (Suryowinoto, 2001; 2004; Tim Peneliti Unud, 2002; LPM UNUD, 2004) karena warna buah pinang yang ranum kulitnya merah. Kalau pinang terkendala dalam memperolehnya bisa dipakai manggis (Garcia mangostana L.) (Suryowinoto, 2001; 2004; Tim Peneliti Unud, 2002; LPM UNUD, 2004), karena kulit buah manggis ranum berwarna merah sampai merah tua.

a.5) Sedangkan untuk lokasi di tengah-tengah simbulnya 5 warna; dipakai buah nenas (Ananas comosus L.) (Suryowinoto, 2001; 2004; Tim Peneliti Unud, 2002; LPM UNUD, 2004). Alasannya apakah ke lima warna ada pada buah nenas tersebut? Sejak buah muda sampai ranum memang ke lima warna ada pada buah nenas. Itulah kenyataannya. Itu mengenai buah tanaman sebagai bagian elementer sesajen.

b. Jenis kelapa. Buah kelapa diperlukan dalam proses pembuatan sesajen. Dalam Budaya Bali kelapa ada beberapa jenis, seperti: nyuh bulan dalam pangider-ideran lokasinya di timur; nyuh udang lokasinya di selatan; nyuh gading lokasinya di barat; nyuh mulung lokasinya di utara; nyuh suda-mala lokasinya di tengahtengah. Sedangkan yang arah menyilang (dik widik) adalah nyuh bojog lokasinya di timur laut; nyuh be-julit lokasinya di barat laut; nyuh rangda lokasinya di tenggara; dan nyuh surya lokasinya di barat daya. Semua jenis kelapa tersebut digunakan sebagai sarana dalam membuat banten seperti banten panyegjeg, pulakerti, tetukon, dan yang lainnya. Lokasi buah kelapa disusun sesuai dengan arah mata 
angin (pangider-ideran) di atas (Adiputra \& Wadi, 2015). Di samping buah kelapa yang matang, juga diperlukan kelapa muda (bungkak) untuk air penyucian. Yang diperlukan juga kelapa muda jenis kelapa di atas tadi. Daun kelapa muda/janur (busung) juga dipakai dalam merangkum catur-dhala atau panca-dhala. Daun kelapa muda (busung) lokasinya di barat sesuai dengan warna kuning simbul Dewa Maha Dewa. Masih ada 2 jenis kelapa lainnya, yaitu nyuh bongol, buah kelapa yang sudah tua, tetapi tidak ada suara air di dalam buah tersebut, bila diguncang-guncang. Yang lainnya lagi nyuh buta, yaitu buah kelapa kalau dikupas sabutnya ternyata dalam puncak tempurungnya tidak ada matanya. Ke dua jenis kelapa tersebut, dipakai minyak (sama seperti jenis kelapa lainnya) yang dimanfaatkan dalam pengobatan tradisional.

c. Panca dhala. Daun tanaman, dituliskan dalam pelutuk bebantenan (Sudarsana, ) bahwa ada istilah panca dhala. Dhala berarti daun. Lima jenis daun tanaman yang dipakai sarana dalam persembahan yadnya, sesuai dengan arah mata angin (pangider-ideran) tadi. Untuk timur warna putih, dipakai daun duren (durian= Durio zitbethinus Murr.) (Suryowinoto, 2001; 2004; Tim Peneliti Unud, 2002; LPM UNUD, 2004), karena warna daun durian di bagian bawah daunnya berwarna putih mengkilap. Di Barat, warna kuning dipakai busung, daun muda kelapa (Cocos nucifera L.) (Suryowinoto, 2001; 2004; Tim Peneliti Unud, 2002; LPM UNUD, 2004), karena memang warnanya kuning. Sedangkan yang di utara dipakai daun buah/pinang (Areca catechu L.) (Suryowinoto, 2001; 2004; Tim Peneliti Unud, 2002; LPM UNUD, 2004), karena simbul warna hitam/gelap daun pinang. Di selatan dipakai daun buluwan (Nephellium lappaceum L.) (Suryowinoto, 2001; 2004; Tim Peneliti Unud, 2002; LPM UNUD, 2004). Di tengah-tengah dipakai daun salak (Zalacca edulis Reinw.) (Suryowinoto, 2001; 2004; Tim Peneliti Unud, 2002; LPMUNUD, 2004), mungkin karena ke-5 warna itu ada dalam setangkai daun salak, putih dari daunnya, merahnya warna duridurinya, hitamnya warna dasar daun, kuningnya warna lapisan pelepah daunnya. Susunan tersebut dipakai sarana upacara (upakara) banten tetukon dalam pitra yadnya, atau sarad untuk manusa dan dewa yadnya (Ida Pedanda Istri Manuaba, 2016)..

d. Sapta laywan. Untuk manusa yadnya dan dewa yadnya dipakai 7 daun sehingga disebut sapta laywan terdiri dari daun: pelasa (Butea monosperma Tamb.), ancak (= Ficus rumphii L), sokasti (Ixora paludosa L), beringin (Ficus benjamina L.), nagasari (Mesu ferrea L.), cemara (pinus $=$ Casuarina equisetifolia $J R$ \& G Frost.) dan bunga pinang (belangsah $=$ Catechu indica L.) (Suryowinoto, 2001; 2004; Tim Peneliti Unud, 2002; LPM UNUD, 2004). Semua daun tersebut digulung, paling luar don pelasa, ancak, sokasti, cemara, dan bunga pinang paling dalam dan diikat dengan benang. Dipergunakan menyusun banten catur. Banten catur dipersiapkan kalau tingkatan upacara tersebut tergolong upacara madya dan utama saja (Suryowinoto, 2001; 2004; Tim Peneliti Unud, 2002; LPM UNUD, 2004).

e. Sekah. Dalam pitra yadnya, atma wedana atau ngeroras, selalu dibuat sekah. Bahannya adalah sebuah kelapa muda (kelungah). Di luarnya dibentuk kerangka meruncing dan dipuncaknya bentukan mahkota dengan gambaran muka terbuat dari kayu cendana (Santalum album L.), yang dihias dengan bunga medori putih (Calotropis gigantean L.) (Suryowinoto, 2001; 2004; Tim Peneliti Unud, 2002; LPM UNUD, 2004), dan tunjung merah (Nelumbium nelumbo Druce) (Suryowinoto, 2001; 2004; Tim Peneliti Unud, 2002; LPM UNUD, 2004). Sedangkan dalam tubuh kerangka tersebut ditusuk-tusuk berurutan daun beringin (Ficus benjamina L.) (Suryowinoto, 2001; 2004; Tim Peneliti Unud, 2002; LPM UNUD, 2004) sebanyak 20 lembar untuk wanita, dan 22 lembar untuk pria. Itulah yang membentuk sekah sebagai perwujudan dari insan yang diupacarai.

f. Dewa-dewi. Untuk upacara Dewa yadnya ada susunan upakara bernama Dewa-dewi yang disusun dari don ancak (bodi= Ficus rumphii L.) (Suryowinoto, 2001; 2004; Tim Peneliti Unud, 2002; LPM UNUD, 2004) yang dirangkai tersendiri, dan don bingin (Ficus benjamina L.) (Suryowinoto, 2001; 2004; Tim Peneliti Unud, 2002; LPM UNUD, 2004) yang dirangkai sendiri, ditaruh di atas beras sebagai penyusun utamanya. 
g. Bija ratus. Apa yang dimaksud bija ratus itu? Tidak lain campuran dari buah rumput-rumputan yang warnanya sesuai dengan simbul warna arah mata angin. Biji yang berwarna putih dipakai beras (Oryza sativum L.) (Suryowinoto, 2001; 2004; Tim Peneliti Unud, 2002; LPM UNUD, 2004) atau jagung nasi putih (Zea mays L.) (Suryowinoto, 2001; 2004; Tim Peneliti Unud, 2002; LPM UNUD, 2004). Untuk biji berwarna kuning dipakai jagung kuning (Zea mays L.) atau beras ketan (Oryza sativum Alutinosa) (Suryowinoto, 2001; 2004; Tim Peneliti Unud, 2002; LPM UNUD, 2004). Untuk warna hitam simbul utara dipakai godem (Eugenia domestica Baill.) (Suryowinoto, 2001; 2004; Tim Peneliti Unud, 2002; LPM UNUD, 2004) atau beras injin (Oryza sp) (Suryowinoto, 2001; 2004; Tim Peneliti Unud, 2002; LPM UNUD, 2004). Untuk arah selatan (warna merah) dipakai jawa () (Suryowinoto, 2001; 2004; Tim Peneliti Unud, 2002; LPM UNUD, 2004) atau beras merah (Oryza sativum Montana) (Suryowinoto, 2001; 2004; Tim Peneliti Unud, 2002; LPM UNUD, 2004). Untuk di tengah-tengah dipakai isi buah jail-jali (Coix lacryma jobi L.) (Suryowinoto, 2001; 2004; Tim Peneliti Unud, 2002; LPM UNUD, 2004).

h. Daun beringin (Ficus benjamina L.) (Suryowinoto, 2001; 2004; Tim Peneliti Unud, 2002; LPM UNUD, 2004). Di samping sebagai tanaman magis, beringin juga sebagai tanaman upacara. Misalnya sewaktu pitra yadnya nyekah atau ngeroras atau atma wedana, ada acara ngangget don bingin. Dalam upacara tersebut ada upacara khusus dipimpin oleh pendeta nunas daun beringin (Adiputra, 2017) untuk dipakai dalam menyusun sekah sebagai perwujudan dari fisik yang diupacarai. Di samping itu dalam menyusun banten sarad dan sate wayang, dipakai pula makna pohon beringin sebagai salah satu tanaman suci dan magis. Sate sebagai wujud dari beringin adalah bentukan satai yang paling tinggi (nomor satu) dan berlokasi di tengah-tengah; disusul oleh tanaman bodi sebagai nomor dua. Sedemikian pentingnya makna pohon beringin.

i. Pule (pulai, Alstonia scholaris L.) (Suryowinoto, 2001; 2004; Tim Peneliti Unud, 2002; LPM UNUD, 2004). Disimbulkan sebagai tanaman magis, yang keberadaannya biasanya di daerah hutan pura. Pohonnya besar dan tinggi, termasuk tanaman obat, yang dicari adalah kulit batangnya. Kayu pule sudah umum diketahui sebagai bahan untuk membuat punggalan barong, tapel rangda atau tapel raksasa atau tapel lainnya. Untuk itu, sejak mulai memohon kayunya sudah dipilih hari baik, dan bukan memotong batang atau dahan kayunya, tetapi dengan cara ngepel. Memotong hanya sebesar yang diperlukan kemudian sisi kiri dan kananya tinggal dilepaskan saja. Jadi pohonnya tetap berdiri tegak.

j. $\quad$ Banten catur. Catur adalah wujud sesaji yang di dalamnya harus ada semua jenis biji-bijian dari berbagai kacang, dan kara dengan berbagai komponen dan aksesori lainnya. Kacang yang dimaksud adalah kacang panjang (Vigna sinensis L.), kedele (Glycine max Merr) (Suryowinoto, 2001; 2004; Tim Peneliti Unud, 2002; LPM UNUD, 2004), kacang merah (Phaseolus vulgaris L.), undis (Cajanus indicus Spreng), komak (Dolicho lablab L.), kacang ranti, semua jenis kara (Phaseolus lunatus L.), kecipir (Psophocarpus tetragonolobusDC.) (Suryowinoto, 2001; 2004; Tim Peneliti Unud, 2002; LPM UNUD, 2004), dan kacangijo (Phaseolus radiates L.) (Suryowinoto, 2001; 2004; Tim Peneliti Unud, 2002; LPM UNUD, 2004).

k. Banten panyegjeg. Komponen utamanya, jenis jajan yang dibuat khusus untuk itu, di samping buah atau daun tanaman juga tanaman utuh, seperti cempaka putih (Michelia alba L.), cempaka kuning (Michelia champalla L.), pinang (Areca catechu L), palem (), uduh ()?

Menurut kebiasaan atau dresta dari pemakaian buah-buahan tersebut sebagai sesajen disusun sedemikian rupa ada dalam bentuk banten tumpuk atau tegen-tegenan. Kalau khusus hanya disusun dari buah-buahan saja disebut banten pala gantung. Atau kalau khusus bahannya hanya jenis umbiumbian seperti ketela rambat (Ipomoea batatas L.), keladi (Colocasia esculanthum Schott), biaung (Dioscorea aculeate L.), kentang (Solanum tuberosum L.), ketela pohon (Manihot esculenta Crantz), ubi (Batatas edulis Chois.) (Mardisiswoyo dan Harsono, 1987; Suryowinoto, 2001; 2004; Tim 
Peneliti Unud, 2002; LPM UNUD, 2004) maka disebut sebagai banten pala bungkah (Adiputra, 2017).

Bentuk lainnya adalah dengan berbahan buah dan daun disusun dalam bentuk struktur bangunan banten. Biasanya upacara dengan tingkatan sedang (madya) sampai utama memakai buah dan daun tanaman tertentu. Untuk buah ada 5 tanaman, seperti: ceroring (duku; Lansium domesticum L. ). crème (Phyllanthus acidus L.), manggis (Garcinia mangosta L.), nenas (manas; Ananas comosus L.), pangi (Mangifera indica L.) (Mardisiswoyo dan Harsono, 1987; Suryowinoto, 2001; 2004; Tim Peneliti Unud, 2002; LPM UNUD, 2004). Dalam menyusun banten penempatan buah-buahan tersebut sebagai berikut: duku ditempatkan di arah barat dari alas banten. Cerme ditempatkan di arah timur; nenas ditempatkan di tengah-tengah; manggis di arah selatan; dan buah pangi di arah utara. Seandainya ada kendala dalam memperoleh buah-buahan tersebut untuk yang di utara pangi bisa diganti dengan poh (Mangifera indica L) (Adiputra, 2017). Buah manggis bisa diganti dengan buah pinang (Areca catechu L.). Cereme bisa dengan tingkih (kemiri, Aleurites moluccana Willd.), untuk ceroring bisa diganti dengan buah pisang (Musa spec.) (Mardisiswoyo dan Harsono, 1987; Suryowinoto, 2001; 2004; Tim Peneliti Unud, 2002; LPM UNUD, 2004).

Sedangkan daun tanaman penempatannya juga seperti itu, dengan alasan sesuai dengan simbul warna arah mata angin. Nama banten tersebut misalnya adalah tetukon untuk pitra yadnya, sesaji dan pula kerti untuk dewa yadnya. Penempatan buah atau daun waktu menyusun banten tersebut (metanding) selalu disesuaikan dengan warna simbul arah mata angin di atas, tidak boleh ditukar-tukar. Itu makanya semua jenis tanaman tersebut dalam melaksanakan yadnya madya sampai utama harus dicari sampai dapat karena keberadaannya mutlak sebagai simbul alam yang akan dipersembahkan kepada Tuhan/ Sanghyang Widi.

Makna dari informasi tersebut di atas bahwa dalam kaitan yadnya warga desa pekraman harus dan wajib melestarikan keberadaan tanaman tersebut demi pelaksanaan upacara yadnya. Sebaiknya, supaya diupayakan oleh pemimpinnya agar setiap tanaman yang diperlukan tersebut selalu ada di tiap tiap desa yang bersangkutan (Tim Penyusun, 2002; Adiputra, 2008; 2011). Bagaimana caranya tergantung kepada kondisi; bisa saja dalam bentuk taman tanaman upacara, atau ditanam di sekitar pura yang ada daerah kosongnya, atau ditanam di area hutan yang menjadi bagian pura (Tim Penyusun, 2002; Adiputra, 2011). Juga secara perorangan di kebun masing-masing untuk jenis kelapa dan pisang atau buah-buahan lainnya.

Aspek berikutnya, demikian tanaman tersebut bisa ditanam, semestinya disosialisasikan ke seluruh masyarakat dengan membuat taman tanaman obat, upacara, magis, dan yang lainnya. Kalau hal itu bisa diwujudkan maka taman tersebut akan menjadi media dan asset pendidikan bagi generasi muda, asset pariwisata, dan asset kerjasama penelitian (Leurs, 2010; Adiputra, 2011). Sangat ideal kalau di setiap desa pakraman bisa didirikan taman-taman tanaman tersebut. Hal itu hendaknya menjadi kepedulian pemimpin, anggauta masyarakat dan NGO di wilayah tersebut (Adiputra, 2017). Semestinya pula pemerintah daerah mendukung upaya pelestarian tersebut dengan menyediakan diri sebagai fasilitator di masing-masing desa pakraman, guna revitalisasi budaya local (Leurs, 2010).

\section{Simpulan dan Saran}

Dari pembahasan di atas dapat ditarik simpulan sebagai berikut:

1) dalam mempersiapkan upakara suatu yadnya banyak menggunakan buah, daun, umbi, bunga, sehingga disebut tanaman tersebut sebagai tanaman upacara;

2) dalam setiap yadnya yang dimaksud segala upaya dikerahkan untuk mendapatkan tanaman upacara tersebut;

3) pemanfaatan buah atau daun tanaman upacara mengacu pada pelutuk bebantenan agar sesuai dengan simbul warna arah mata angin;

4) wujud upakara yadnya bisa berupa: banten tumpuk, tegenan, banten pala bungkah, banten pala gantung, banten catur, dewadewi, pula kerti, pesaji, panyegjeg dan lainnya.

5) pemanfaatan tanaman sebagai bagian dari sesajen disesuaikan dengan arti warna buah atau daun dalam pangider-ideran.

Saran-saran:

1) sebaiknya pelestarian tanaman upacara segera diupayakan di setiap desa pekraman ;

2) usaha tersebut dimulai dari tanaman yang paling 
mudah didapatkan, sampai kepada tanaman upacara yang sangat langka;

3) wujud pelestarian bisa saja dimulai dari masingmasing keluarga dengan memanfaatkan pekarangan rumah untuk berbagai jenis bunga, atau kebun untuk tanaman berbuah;

4) pekarangan pura atau hutan di sekitar pura dapat dipakai sebagai taman tanaman upacara;

5) setiap desa pekraman ikut bertanggung jawab dalam pelestarian tanaman upacara tersebut.

\section{Daftar Pustaka}

1. Adiputra, N. 1999. Tanaman Obat Sebagai Bahan Makanan Orang Bali. MKU. No. 30.

2. Adiputra, I N. 2004. Tanaman obat sebagai bahan obat, menurut Lontar Usada Bali. Majalah Kedokteran Udayana. 35(123). Januari: 35-44.

3. Adiputra, N. 2005. Tanaman Obat Yang Ditanam di Telajakan Pekarangan Rumah Sebagai Tanaman Hias. MKU. Vol.36 (127)

4. Adiputra, I N. 2005.a. Tanaman hias beberapa hotel di Denpasar dan Badung yang bernilai sebagai tanaman obat. Majalah Kedokteran Udayana.36(127). Januari: 3647.

5. Adiputra, I N. 2005.b. Pemnafaatan tanaman obat sebagai tanaman hias pada median jalan di Denpasar. Majalah Kedokteran Udayana.36(129). Juli: 178-185.

6. Adiputra, I N. 2005.c. Tanaman hias dan pelestarian lingkungan. Editorial. Majalah Kedokteran Udayana. 36(128). April: 77.

7. Adiputra, I N. 2006.a. By SHIP Approach preserving and conserving the medicinal plants in Bali. Paper presented on The "Ergo-Future2006" International Symposium and Workshop on Ergonomics and Occupational Health, November 28-30, 2006 in Denpasar.

8. Adiputra, I N. 2006.b. Tanaman obat yang digunakan sebagai anti-virus di Bali. Majalah Kedokteran Udayana.37(134). Oktober 2006: 255-260.
9. Adiputra, I N. 2006.c. Tanaman hias yang bernilai tanaman obat di beberapa kantor pemerintah di Kabupaten Badung dan Kodya Denpasar. Majalah Kedokteran Udayana.37(131). Anuari 2006: 29-38.

10. Adiputra, I N. The systemic, holistic, interdisciplinary and participatory (SHIP) Approach supports the conservation program of medicinal plants in Bali. Journal of Human Ergology. 36(2). 2007a: 51-55.

11. Adiputra, I N. Otokritik dalam pemanfaatan usadha sebagai sumber informasi pengobatan tradisional di Bali. MEDICINA. 38(3). September 2007b: 218-224.

12. Adiputra,IN. Strategi Pelestarian tanaman obat dalam perspektif budaya. BUMI LESTARI. 8(1). Februari 2008: 63-73.

13. Adiputra,I N. Horticultural, medicinal and ceremonial plants in Petiga illage, Tabanan, Bali Province. BUMI LESTARI. Jurnal Lingkungan Hidup. 9(1). Februari 2009: 8796.

14. Adiputra, I N. Tanaman Obat, Tanaman Upacara dan Pelestarian Lingkungan. Dimuat dalam: BUMI LESTARI. Jurnal Lingkungan Hidup. 11(2). Agustus 2011: 342-350.

15. Adiputra, N. Tanaman Obat, Tanaman Upacara dan PelestarianLingkungan. BUMI LESTARI. Jurnal Lingkungan Hidup. 11(2). Agustus 2011:346-354.

16. Adiputra, I N. Manfaat Kembang Telang (Clitoria ternatea L.). Editorial. MEDICINA. 44(2). Mei 2013a: 75-76.

17. Adiputra, I N. Jamu dan Obat Herbal Indonesia. Editorial. MEDICINA. 44(3). September 2013b: 141-142.

18. Adiputra, N. dan Wadi, K. 2015. Kelapa dalam Budaya Bali serta Upaya Pelestariannya. BUMI LESTARI. Jurnal Lingkungan Hidup. Vol.15(1). 2015: 79-86.

19. Adiputra, N. 2017. The Contribution of Traditional Healing on Sustainable Development of Bali. Paper presented on International Seminar in Indonesia Hindu 
University, Denpasar, June 10, 2017 on the theme: "The Concept of Healing in Religion, Culture, Health Science and the Economical Perspective".

20. Anonim. T.t. Lontar Dasaksara. Koleksi Pribadi.

21. Ida Pedanda Istri Manuaba. 2016. Komunikasi Pribadi.

22. Leurs, I N. 2010. Medicinal, Aromatic and Cosmetic (MAC) Plants for Community Health and Bio-Cultural Diversity Conservation in Bali. Indonesia. Dissertation. Leiden University, Leiden Ethnosystems and Development Program Studies No. 5; Leiden, Holland.

23. LPMUNUD. 2004. Gumi Bali Banten. Denpasar.

24. Mardisiswoyo, Sudarman dan Harsono Rajakmangun Sudarso. 1987. Cabe Puyang Warisan Nenek Moyang. 2. Penerbit alai Pustaka. Jakarta.
25. Nala, I Gusti Ngurah dan Adia Wiratmadja. 1993. Murddha Agama Hindu. Penerbit Upada Sastra. Denpasar.

26. Tim Penelitian Penterjemahan Lontar Usada Bali. 1983. Usada Mala. Universitas Udayana, Denpasar: 476.

27. Tim Penyusun. 2002. Koleksi Tanaman Upacara Adat Bali. Kebun Raya Eka Karya Bali. UPT Balai Konservasi Tumbuhan Kebun Raya Eka Karya Bali-LIPI. Vol. 1No.1. Tabanan.

28. Suryowinoto, SM.2001. Flora Eksotika. Tanaman Peneduh. Cetakan ke-5. Penerbit Kanisius. Yogjakarta.

29. Suryowinoto, S M. 2004. Flora Eksotika. Tanaman Hias Berbunga. Cetakan ke-6. Penerbit Kanisius. Yogjakarta. 